\title{
Menelaah Teori Anti-Sinonimitas Bintu Al-Syathi' sebagai Kritik terhadap Digital Literate Muslims Generation
}

\author{
Alif Jabal Kurdi dan Saipul Hamzah \\ UIN Sunan Kalijaga Yogyakarta \\ alifjabalkurdi@gmail.com
}

\begin{abstract}
The flexibility in using digital media as a result of the incessant era of globalization is a phenomenon which cannot be avoided at this time. This phenomenon also has implications for the realm of religion where there are many al-Qur'an and translation applications that are called new mushaf. The existence of this new mushaf, also has an impact on the formation of a new Muslim generation which by Muhammad Sahal Sobirin is called Digital Literate Muslims Generation, a generation of Muslims who depend on the use of al-Qur'an and translation applications. In order to respond to this phenomenon, this article was prepared by emphasizing aspects of i'jazal-Qur'an based on the theory of la taradufa fi al-Qur'an in Aisyah Abdur Rahman bintu Syathi's perspective, as an affirmation of the complexity of the divine message of al-Qur'an that cannot be achieved only by understanding translation.
\end{abstract}

Keywords: Bintu Syathi', La Tarādufa fi al-Qur'an, Digital Literate Muslims Generation, Criticism

\section{Abstrak}

Keleluasaan dalam penggunaan media digital sebagai buah dari gencarnya era globalisasi adalah sebuah fenomena yang tidak dapat dihindari saat ini. Fenomena itu juga berimplikasi pada ranah agama dimana banyaknya pembuatan aplikasi-aplikasi al-Qur'an dan terjemah yang disebut sebagai new mushaf. Adanya new mushaf ini, juga berdampak pada terbentuknya sebuah generasi muslim baru yang oleh Muhammad Sahal Sobirin disebut dengan Digital Literate Muslims Generation, sebuah generasi muslim yang bergantung pada penggunaan aplikasi al-Qur'an dan terjemahan. Demi merespon fenomena tersebut, artikel ini disusun dengan menekankan aspek i'jazalQur'an berdasarkan teori la taradufa fi al-Qur'an dalam perspektif Aisyah Abdur Rahman bintu Syathi', sebagai peneguhan akan kompleksitas pesan ilahiyah al-Qur'an yang tak akan mampu digapai hanya dengan memahami terjemahan.

Kata Kunci: Bintu Syathi', La Tarādufa fi al-Qur'an, Digital Literate Muslims Generation, Kritik 
Millatī, Journal of Islamic Studies and Humanities, Vol. 3, No. 2, Des. 2018: 245-260

\section{Pendahuluan}

Bahasa Arab adalah merupakan bahasa yang memiliki kekayaan kosa kata yang sangat melimpah, betapa banyak kosa kata di dalam al-Qur'an yang mungkin dianggap memiliki makna yang sama, namun hakikatnya sangat berbeda dalam penerapannya karena masing-masing kosa kata memiliki aksentuasi yang berbeda seperti halnya sinonimitas dalam al-Qur'an dalam bahasa Arab disebut dengan taräduf yang meski dalam arti sama seperti kata halafa dan aqsama. Akan tetapi jika ditarik ke makna spesifiknya maka akan berbeda penerapannya, dan salah satu ulama yang tidak setuju adanya sinonimitas dalam al-Qur'an adalah Bintual-Syathi' yang dikenal sebagai ahli sastra dan sosok ulama (mufasir) yang kontemporer yang masyhur.

Teori la taradufa fi al-Qur'an ini merupakan sebuah teori menekankan kepada aspek i'jaz al-Qur'an. Dimana tidak ada satupun kata dalam al-Qur'an yang dianggap memiliki makna yang sama meskipun dianggap-pada umunyasebagai kata yang mutarädif (bersinonim). Aplikasi teori la taradufa fi al-Qur'an dalam sudut pandang Bintu al-Syathi' tercakup dalam bukunya yang berjudul "al-I'jaz al-Bayani li al-Qur'an"'. Jika merujuk pada artikel-artikel yang membahas secara spesifik kitab ini. penulis justru condong menemukan artikel yang membahas kitab tafsir yang beliau yang berjudul "al-Qur'an wa Qadhayat alInsan” ${ }^{2}$.

Dalam kaitannya sebagai apresiasi terhadap realita zaman sekarang yang serba digital. Maka lahirlah dua buah istilah baru yang dimunculkan oleh Muhammad Sobirin Sahal dalam ranah interaksi media dengan agama. Kedua istilah tersebut ialah new mushaf yang digunakan dalam untuk menyatakan aplikasi al-Qur'an dan terjemahannya secara digital. Sedangkan kata yang kedua adalah digital literate muslims generation yang ditujukan kepada pengguna new mushaf yakni para generasi muslim yang memiliki ketergantungan dalam penggunaan aplikasi al-Qur'an dan terjemahan. ${ }^{3}$

Maka atas dasar itulah, rasanya ada beberapa hal yang perlu diurai dan dikritisi terkait budaya baru generasi muslim yang memiliki ketergantungan

1 Aisyah Abdurrahman Bintu al-Syathi', al-I'jaz al-Bayani li al-Qur'an, Kairo: Dar alMa'arif, 2008, h. 211-240.

${ }^{2}$ Aisyah Abdurrahman Bintu al-Syathi', al-Qur'an wa Qadhayat al-Insan, Mesir: Dar al-Ma'arif, 1964.

${ }^{3}$ Muhammad Sahal Sobirin, "Digital Qur'an and Its Translation”, dalam Digital Religion: Understanding Religious Practice in New Media World, London: Routledge, 2013, h. 1. 
kepada aplikasi al-Qur'an dan terjemah, guna mencegah adanya dampak negatif yang akan ditimbulkan kemudian.

\section{Bintu al-Syathi': Sekilas Tentang Kelahiran dan Latar Belakang Kehidupan Keluarga}

Diwilayah sebelah barat Delta Nil, tepatnya di Dumyat, Aisyah 'Abd al-Rahman yang dikenal dengan nama samaran Bint al-Syathi'. Lahir pada tanggal 6 november 1913. Ia tumbuh dalam lingkungan keluarga muslim yang taat dan tergolong konservatif. ${ }^{4}$ Walaupun mempunyai pandangan yang konservatif, ia memiliki semua daya tarik seorang perempuan Arab modern yang berbudaya, yang harus diperhitungkan, dan dicirikan oleh kemampuan pengungkapan diri yang kuat dan artikulatif berdasarkan nilai-nilai Islam dan informasi pengetahuan yang luas. ${ }^{5}$

Pada masa kecil, Bintu al-Syathi' hampir tidak memiliki waktu untuk bermain dengan teman-teman sebayanya. Karena ayahnya selalu mengajaknya di kamarnya baik di rumah maupun di kantornya di Universitas al-Bahr agar ia bisa saling menyimak al-Qur'an yang dibaca ayahnya dan temannya. Berkat kemampuan intelektual yang dimilikinya, ia mampu menghafal beberapa ayat al-Qur'an, terutama surah-surah pendek dalam al-Qur'an yang berulangkali dibaca. ${ }^{6}$ Nama Bintu al-Syathi'mulai dikenal khalayak ramai karena studinya tentang sastra Arab dan Tafsir al-Qur'an. Pada tahun 1990-an ia kerap memberi ceramah keagamaan kepada para sarjana di Roma, Aljazair, Baghdad, New Delhi,Kuwait, Rabat, Khartoum, Fez, dan Yerussalem. Pada tahun 1997-an ia dinobatkan sebagai profesor sastra dan bahasa Arab di Universitas 'Ain Syam Mesir. Kadang-kadang ia juga menjadi profesor tamu disejumlah Universitas Qarawiyyin Maroko.?

Kiprah intelektual Bintu al-Syati' dalam pengembangan ilmu-ilmu keagamaan bahasa dan sastra Arab, telah dimulai sejak dia masih dalam bimbingan guru-gurunya. Karena itu tidak mengherankan kalau disebutkannya

${ }^{4}$ Wahyuddin, "Corak dan Metode Interpretasi Aisyah Adbdurrahman Bint al-Syathi", AL-Ulum, Vol. 11, No. 1, Juni 2011, h. 82.

${ }^{5}$ Mudzakkir Abdusaalam, Tafsir Bintusy Syathi, Bandung : Penerbit Mizan, 1999, h. 11.

${ }^{6}$ Wahyuddin, "Corak dan Metode Interpretasi Aisyah Adbdurrahman Bint al-Syathi”, AL-Ulum, Vol. 11, No. 1, Juni 2011, h. 83.

7 Saiful Amin Ghofur, Mozaik Mufasir Al-Qur'an dari Klasik hingga Kontemporer, ( Yogyakarta : Kaukaba Dipantara, 2013) h. 148. 
Millatī, Journal of Islamic Studies and Humanities, Vol. 3, No. 2, Des. 2018: 245-260

bahwa dia adalah seseorang ilmuwan Islam sekaligus sastrawati yang produktif. Disamping sebagai dosen , ia juga adalah seorang pengarang produktif dan malah lebih dikenal sebagai kritikus sastra, disamping menekuni studi-studi al-Qur'an, yang dikatakannya sebagai kitab terbesar dalam bahasa Arab-baikdari segi bahasa maupun dari segi kandungannya maupun dari segi isinya ${ }^{8}$. Bintu al-Syathi' adalah seorang mufasir produktif yang sangat jarang dijumpai. Karya-karyanya tidak hanya terbatas pada kajian al-Qur'an semata, melainkan juga lintas ilmu. ${ }^{9} \mathrm{Di}$ antara karya-karya monumentalnyayang telah dipublikasikan, ada karya yang bersifat umum seperti Umm al-Nabi, Nisa al-Nabi, Al-Hayah al-Insaniyyah 'Inda Abi Lahab. Adapun yang memiliki tema khusus yakni kajian al-Qur'an diantaranya al-Tafsir bayani lo al-Qur'an al-Karim, al-Qur'an wa al-Tafsir al-Ashri, al-Israiliyyah fi al-Ghazw al-fikr, Al-I'jaz al-Bayaniy li al-Qur'an. ${ }^{10}$

\section{Teori Anti Sinonimitas dalam al-Qur'an}

Sinonim adalah bentuk bahasa atau kata yang maknanya mirip atau sama dengan bentuk bahasa atau kata lain. ${ }^{11}$ Dalam bahasa Arab dikenal dengan istilah al-tarāduf. Secara terminologis, sinonimitas atau al-tarādufadalah dua kata atau lebih yang memiliki satu arti ketika dilihat dari akar katanya. Sedangkan antisinonimitas adalah dua kata atau lebih yang tidak memiliki satu arti. Seperti perkataan cantik dengan perkataan indah, manusia dengan insan.

Jika dirujuk berdasar pendapat ulama, maka sebagian besar atau mayoritas ulama menolak adanya sinonimitas dalam al-Qur'an, alias berteori bahwa setiap kata dalam al-Qur'an bersifat anti-sinonim. Adapun ulama yang berpegang pada pendapat bahwa terdapat sinonimitas dalam al-Qur'an antara lain Sibawaih, Khalil, dan Suyuthi. Sedangkan ulama yang menyatakan penolakan diantaranyaseperti Ibn al-'Arabi,Ahmad bin Yahya Sa'lab, Ahmad bin Faris dalam karyanya yang berjudul as-Shahibi, Ibn Dastarwaih dalam karyanya yang berjudulTashi@bal-Fasi@h, Abu Hilal al'Askaridalam karyanyaal-Mufradat fi@ Garib al-Qur'an, Abu Ishaq al-Isfarayini, dan sebagainya. Mereka berhujjah bahwa setiap kalimat dalam bahasa Arab (al-Qur'an) memiliki makna yang spesifik, yang

${ }^{8}$ Mardan , " Tafsir Karya 'Aisyah 'Abd al-Rahman Bint Syathi' Suatu Rekontruksi Metodologi Tafsir Kontemporer”, dalam Adabiyah, Vol. XI, No. 2. 2011, h. 167.

${ }^{9}$ Wahyuddin, "Corak dan Metode Interpretasi Aisyah Adbdurrahman Bint al-Syathi'”, AL-Ulum, Vol. 11, No. 1, Juni 2011, h. 125.

${ }^{10}$ Mardan , " Tafsir Karya 'Aisyah 'Abd al-Rahman Bint Syathi' Suatu Rekontruksi Metodologi Tafsir Kontemporer”, Adabiyah, Vol. XI, No. 2. 2011, h. 168.

${ }^{11}$ Kbbi.kemdikbud.go.id/entri/Sinonim, diakses pada 04/04/2018. 
membedakan antara satu kalimat dengan lainnya. ${ }^{12} \mathrm{M}$. Quraish Shihab, pakar tafsir Indonesia, juga termasuk ulama yang menolak adanya sinonim murni dalam al-Qur'an. Ia mengungkapkan kaidah umum mengenai mutarädif yakni, tidak ada dua kata yang berbeda kecuali pada perbedaan maknanya. ${ }^{13}$

Dan beberapa pemikir muslim kontemporer yang menggunakan dan mengembangkan metode anti-sinonimitas dalam menafsirkan al-Qur'an diantaranya adalah Muhammad Syahrur dan Bintu al-Syathi'. Muhammad Syahrur dalam karya monumentalnya al-Kitab wa al-Qur'ān: Qirā'ah Mu'assirah. ${ }^{14}$ Mengingkari adanya tarāduf(sinonimitas), sebab masing-masing kata mempunyai makna yang sesuai dengan konteks ketika kata tersebut disampaikan. Jika seseorang mengakui adanya tarāduf, berarti mengingkari pemkanaan konteks tersebut. Dalam hal ini, Syahrur sepakat dengan pernyataan yang sangat popular dari Sa'lab,ma yuzhannu fi@ dirāsah al-lughawiyyah min al-mutarādifat huwa min al-mutabayyinat. ${ }^{15}$

Adapun Bintu al-Syathi, dalam mengungkapkan pendapatnya tentang anti-sinonimitas, pemikirannya dipengaruhi oleh ulama klasik, diantaranya Abu Hilal al-Asykari, Ibnu al-Arabiy, Abu Qasim al-Anbariy. Dari pemikiran ulama klasik tersebut, ia menyimpulkan bahwa setiap kata yang telah ditetapkan menunjuk pada suatu konteks tertentu, didalamnya mengandung illat atau sebab tertentu yang menyebabkan kata tersebut di ucapkan pada konteks tersebut. Menurut al-Munajjad, al-Anbariy melihat pada kondisi-kondisi eksternal yang berhubungan dengan ucapan suatu kata. ${ }^{16}$

Dalam bukunya al-Tafsir al-Bayani disana dikemukakan bagaimana metodologi teori anti-sinonimitas yang digagas Bintu al-Syathi'. Beliau berkata:

“pertama yang hendaknya dilakukan oleh peneliti makna kosa kata al-Qur'an adalah menghimpun semua kata yang digunakan al-Qur'an menyangkut objek sambil memperhatikan arti-arti yang dapat dikandungnya menurut penggunaan

${ }^{12}$ Waryani Fajar Riyanto, "Antisinonimitas Tafsir Sufi Kontemporer”, Episteme. Vol. 9, No. 1. 2014, h.146-148.

${ }^{13}$ M. Quraish Shihab, Kaidah Tafsir , ( Tangerang : Penerbit Lentera Hati, 2013) h. 124.-125.

${ }^{14}$ Waryani Fajar Riyanto, “Antisinonimitas Tafsir Sufi Kontemporer”, Episteme. Vol. 9, No. 1. 2014, h. 148.

15 Sahiron Syamsuddin, dkk, Hermeneutika al-Qur'an Mazhab Yogya, ( Yogyakarta : Penerbit Islamika 2003), h. 127.

${ }^{16}$ Nabilul Janam, "Sinonimitas Dalam al-Qur'an (Analisis Semantik Lafadz Khauf dan Khasyyah)”, dalam Skripsi Fakultas Ushuluddin dan Dakwah IAIN Surakarta, tahun 2017, h. 24. 
Millatī, Journal of Islamic Studies and Humanities, Vol. 3, No. 2, Des. 2018: 245-260

bahasa, kemudian memperhatikan penggunaan al-Qur'an terhadap kata itu dengan jalan susunan redaksi ayat secara menyeluruh, bukan pada kata yang bisa secara berdiri sendiri terlepas dari konteksnya". ${ }^{17}$

Dari kutipan tersebut diketahui bahwa ada beberapa langkah atau metode yang dilakukan Bintu al-Syathi' dalam menerapkan teorinya. Pertama, mencari makna asli sebuah kosa kata berdasarkan kamus serta menghimpun ayat-ayat yang di dalamnya tercakup kosa kata tersebut. kedua, setelah menemukan makna aslinya, maka yang perlu dilakukan adalah mencari makna relasionalnya dalam al-Qur'an dengan membaca redaksi yang mencakup kosa kata tersebut secara utuh. Ketiga, menelaah penisbatan kosa kata tersebut terhadap subjek ataupun objek tertentu.

\section{Aplikasi Teori 'Adam al-Taraduf Bintu Syathi'}

Setelah pada bab sebelumnya dipaparkan selayang pandang tentang teori 'adam al-taraduf atau la taradufa fi al-Qur'an. Maka pada bagian pembahasan ini akan ditampilkan beberapa kata yang umumnya dikatakan bersinonim namun faktanya di dalam al-Qur'an, kata-kata tersebut memiliki makna berbeda maupun fungsinya masing-masing.

Pada pembahasan ini akan diuraikan bagaimana teori Bintu Syathi' diaplikasikan dengan mengambil beberapa sample kata yang umumnya dikatakan

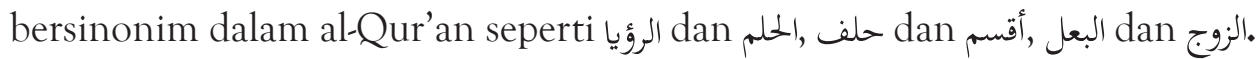

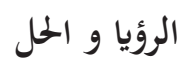

Dalam kebanyakan kamus, kata al-hulmdimaknai dengan kata al-ru'ya. ${ }^{18}$ Hal ini mengindikasikan seolah-olah kedua kata ini bermakna sama. Kata al-hulm sendiri sebenarnya memiliki beberapa makna, diantaranya mimpi ${ }^{19}$, pikiran $^{20}$, baligh $^{21}$, dan lembut ${ }^{22}$. Maka untuk menempatkan makna yang tepat tentunya

${ }^{17}$ M. Quraish Shihab, Kaidah Tafsir,Tangerang : Penerbit Lentera Hati, 2013, h. 124.

${ }^{18}$ Ditelusuri melalui mu'jam digital, www.almaany.com, diakses pada 03/04/2018.

${ }^{19}$ Q.S Yusuf: 44; Q.S al-Anbiya': 5, lihat Muhammad Fuad Abdul Baqi', al-Mu'jam al-Mufahras li Alfadz al-Qur'an, Bandung: Diponegoro, 2010, h. 275.

${ }^{20}$ Q.S al-Thur: 32.

${ }^{21}$ Q.S al-Nur: 58; 59.

${ }^{22}$ Berasal dari kata حليم yang merupakan shigot mubalaghah, di dalam al-Qur'an kata ini digunakan untuk menunjukkan sifat Allah yang Maha Lembut. Adapun ayat al-Qur'an yang memuat kata ini sangat banyak, dalam al-Mu'jam al-Mufahras terhitung kata tersebut terulang sebanyak 15 kali. Lihat: Muhammad Fuad Abdul Baqi', al-Mu'jam al-Mufahras li Alfadz 
harus diketahui terlebih dahulu bagaimana konteks pembicaraannya (siyāqul kalām).

Dalam al-Qur'an-berdasar penelusuran di atas-kata al-hulm yang bermakna mimpi di temukan tiga kali dan ketiganya berupa bentuk jama' (ahläm) yang menunjukkan ketidakpaduan atau ketidakjelasan, yang tidak bisa dibedakan antara satu mimpi dengan mimpi lainnya atau layaknya mimpi kosong (bunga tidur) semata. ${ }^{23}$

Adapun kata al-ru'ya terulang tujuh kali dalam al-Qur'an dimana seluruhnya memiliki makna al-ru'yah al-shādiqoh. ${ }^{24}$ Ketujuh kata itu juga di dalam al-Qur'an, secara keseluruhan berbentuk mufrod dimana mimpi itu menggambarkan suatu hal yang berbeda (dari bunga tidur pada umumnya), terlihat dan terasa sangat jelas dan jernih. ${ }^{25}$

Dari ketujuh mimpi itu, lima mimpi digunakan al-Qur'an untuk menunjukkan mimpi yang dialami oleh para Nabi sebagai wahyu. ${ }^{26}$ Sedangkan dua mimpi lainnya dialami oleh penguasa kerajaan adalah mimpi yang benar dan merupakan ilham. Namun sayangnya saat mimpi itu ditanyakan kepada para penasihat atau pemuka kerajaannya, mereka justru menanggapinya dengan negatif dan mengatakan bahwa itu adalah mimpi yang kosong atau hanya bunga tidur belaka. ${ }^{27}$

al-Qur'an, (Bandung: Diponegoro, 2010), h. 275.

${ }^{23}$ Aisyah Abdurrahman Bintu Syathi', al-I'jaz al-Bayani li al-Qur'an, Kairo: Dar al-Ma'arif, 2008, h. 215-217. Lihat: Q.S Yusuf : 44; Q.S al-Anbiya': 5.Dalam Q.S Yusuf: 44, disana yang menjadi kunci dimaknainya al-hulm dengan makna al-ru'yah al-kadzibah, kata أَضْغَاثُ أَخْحام ditafsiri oleh penafsir klasik sebagai al-ahlam al-akhlath dan al-ru'yah al-kadzibah yang merupakan jawaban dari para pemuka kerajaan Mesir atas permintaan Rajanya yang ingin agar mimpinya ditafsirkan. Lihat : al-Thabari, Jami' al-Bayan fi Tafsir Ay al-Qur'an, Jilid 16 (Versi Maktabah Syamilah), Saudi: Muasasah al-Risalah, 2000, h. 241; Ibn Katsir, Tafsir al-Qur'an al-Adzhim, Jilid 4 (Versi Maktabah Syamilah), Saudi: Dar Thayyibah, 1999, h. 392.; al-Qurthuby, al-Jami' al-Ahkam al-Qur'an, Jilid 9 (Versi Maktabah Syamilah), Kairo: Dar al-Kutub al-Misriyah, 1964, h. 200.

${ }^{24}$ Q.S Yusuf: 44; Q.S al-Isra': 60; Q.S al-Shaffat (37): 105; Q.S al-Fath (48): 27. Lihat Muhammad Fuad Abdul Baqi', al-Mu'jam al-Mufahras li Alfadz al-Qur'an, (Bandung: Diponegoro, 2010), h. 323. Adapun mimpi yang dimaksud dengan al-ru'yah al-shodiqoh adalah mimpi sejati yang didalamnya wahyu (kepada para Nabi) ataupun ilham. Lihat : Mahmud Abdur Rahim, al-Tafsir al-Nabawi, Kairo: Maktabah al-Zahra', 2000, h. 8.

${ }^{25}$ Aisyah Abdurrahman Bintu Syathi', al-I'jaz al-Bayani li al-Qur'an, Kairo: Dar al-Ma'arif, 2008, h. 215-217.

${ }^{26}$ Mimpi Nabi Ibrahim: Q.S al-Shaffat: 104-105; Mimpi Nabi Yusuf: Q.S Yusuf: 5, 100; Mimpi Nabi Muhammad saw: Q.S al-Isra': 60; Q.S al-Fath: 27.

${ }^{27}$ Aisyah Abdurrahman Bintu Syathi', al-I'jaz al-Bayani li al-Qur'an, Kairo: Dar al-Ma'arif, 2008, h. 215-217. 
Millatī, Journal of Islamic Studies and Humanities, Vol. 3, No. 2, Des. 2018: 245-260

Jadi bisa disimpulkan bahwa antara kata الرؤيا و الحلم di dalam al-Qur'an, memiliki perbedaan makna yang sangat jelas. Meskipun secara umum kedua kata tersebut memilki arti yang sama yakni mimpi. Namun, dalam al-Qur'an ternyata keduanya memiliki fungsinya masing-masing. Dimana kata al-hulm digunakan secara spesifik untuk menunjukkan makna mimpi yang kadzib(bunga tidur), sedangkan kata al-ru'ya digunakan untuk menunjukkan mimpi yang haqi@ qikarena terdapat petunjuk Tuhan di dalamnya, baik berupa wahyu (bagi para Nabi) maupun ilham.

\begin{tabular}{cll}
\hline No. & \multicolumn{1}{c}{ الرؤيl } \\
\hline 1 & $\begin{array}{l}\text { Al-ru'yah al-kadzibah atau mimpi kadzib } \\
\text { (bunga tidur) }\end{array}$ & $\begin{array}{l}\text { Al-ru'yah al-shodiqoh atau mimpi yang } \\
\text { haqiqi (wahyu atau ilham) }\end{array}$ \\
\hline 2 & $\begin{array}{l}\text { Selalu berbentuk jama' dalam al- Selalu berbentuk mufrod dalam al- } \\
\text { Qur'an yang melambangkan ketidak- }\end{array}$ & $\begin{array}{l}\text { Qur'an yang melambangkan kebenar- } \\
\text { an dan kekhasan. }\end{array}$ \\
\hline
\end{tabular}

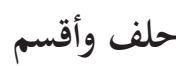

Sangat banyak yang mengira bahwa kedua kata ini saling bersinonim. Bahkan dalam banyak kamus, kedua kata ini tidak dibedakan maknanya. Memang secara umum kedua kata ini bermakna "berjanji atau bersumpah". ${ }^{28}$

Akan tetapi, realitanya di budaya Arab sendiri keduanya memilki kegunaannya masing-masing. Kata halafa biasanya digunakan untuk menyatakan perjanjian atau sumpah yang palsu, sedangkan kata aqsama menyatakan sebaliknya yakni terkait dengan perjanjian yang jujur atau ditepati. ${ }^{29}$

Jika diteliti lebih lanjut di dalam al-Qur'an, akan didapati bahwa kedua kata ini memang tidak bersinonim (asinonim). Dalam al-Qur'an, kata yang berakar dari tiga huruf yakni ح terdapat di 13 tempat. Dan tidak dapat disangkal bahwa seluruh kata itu menunjukkan makna sumpah palsu secara mutlak. Karena pada umumnya, kata halafa memang dinisbatkan penggunannya kepada orang-orang munafiq. ${ }^{30}$

${ }^{28}$ Ditelusuri melalui mu'jam digital, www.almaany.com, diakses pada 03/04/2018.

${ }^{29}$ Aisyah Abdurrahman Bintu Syathi', al-I'jaz al-Bayani li al-Qur'an, Kairo: Dar al-Ma'arif, 2008, h. 221.

${ }^{30}$ Aisyah Abdurrahman Bintu Syathi', al-l'jaz al-Bayani li al-Qur'an, Kairo: Dar al-Ma'arif, 2008, h. 221-222. 
Sedangkan kata aqsama maupun derivasinya yakni kata qasam, digunakan al-Qur'an untuk mensifati atau dinisbatkan kepada subjek baik yang sanggup melaksanakan janji itu atau tidak mungkin ingkar dengan janjinya maupun yang kepada subjek yang memang akan melukai atau mendustai janjinya. Sehingga jika rujuk kepada maknanya, qasam akan memiliki dua makna yakni sumpah asli (pasti ditepati) dan sumpah palsu. ${ }^{31}$ Qasam dalam makna sumpah asli dinisbatkan kepada beberapa subjek, diantaranya Allah ${ }^{32}$ dan Ashabul Jannah ${ }^{33}$. Qasam dalam makna sumpah palsu yang dinisbatkan kepada orang-orang yang bersumpah akan beriman sebelum datangnya Islam. ${ }^{34}$

Maka bisa disimpulkan bahwa kedua kata ini meskipun memiliki kesamaan makna secara umum, namun ada beberapa hal yang membedakan keduanya dalam penggunaannya dalam ayat-ayat al-Qur'an, yakni :

\begin{tabular}{|c|c|c|}
\hline No. & حلف & أقسم \\
\hline 1 & $\begin{array}{l}\text { Mutlak bermakna sumpah } \\
\text { palsu }\end{array}$ & $\begin{array}{l}\text { Memiliki dua makna yakni sumpah asli da sum- } \\
\text { pah palsu, hal ini berdasarkan subjek yang dinis- } \\
\text { batinya }\end{array}$ \\
\hline 2 & $\begin{array}{l}\text { Dinisbatkan kepada orang- } \\
\text { orang munafik }\end{array}$ & $\begin{array}{l}\text { Dinisbatkan kepada Allah dan orang-orang ber- } \\
\text { iman (sumpah asli) dan dinisbatkan juga kepada } \\
\text { orang-orang bersumpah sebelum datangnya Islam } \\
\text { (sumpah palsu) }\end{array}$ \\
\hline 3 & Penggunaanya bersifat khas & Penggunaannya bersifat umum \\
\hline
\end{tabular}

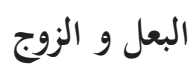

Dalam beberapa kamus, umumnya kedua kata ini selalu dimaknai sama. ${ }^{35}$ Namun sekali lagi, ternyata dalam al-Qur'an keduanya memilki tempat penggunaanya masing-masing. Kedua kata ini memang mempunyai indikasi makna pasangan, akan tetapi perbedaan keduanya akan terlihat mencolok tatkala kita menjumpai bagaimana al-Qur'an memilih kedua diksi ini dan membuatnya nampak jelas bahwa memang sinonimitas tidak berlaku dalam al-Qur'an.

\footnotetext{
${ }^{31}$ Aisyah Abdurrahman Bintu Syathi', al-I'jaz al-Bayani li al-Qur'an, (Kairo: Dar al-Ma'arif,
} 2008), h. 221-222.

${ }^{32}$ Q.S al-Waqi'ah: 76

${ }^{33}$ Q.S al-Ma'idah: 108; 109.

${ }^{34}$ Q.S al-An'am: 109; Q.S Fathir: 42; Q.S al-A'raf 48, 49; Q.S Ibrahim: 44; Q.S al-Nahl: 38; Q.S al-Ma'idah: 53.

${ }^{35}$ Ditelusuri melalui mu'jam digital, www.almaany.com, diakses pada 03/04/2018. 
Millatī, Journal of Islamic Studies and Humanities, Vol. 3, No. 2, Des. 2018: 245-260

Dalam kamus Lisanul 'Arab, kata al-ba'lu memiliki makna asal "sesuatu

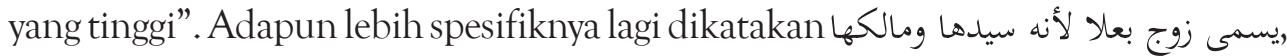
jadi jelas al-ba'lu disana memang dimaknai suami yang telah dukhul (mencampuri istrinya). ${ }^{36}$

Jika telaah berdasarkan ayat al-Qur'an, kata al-ba'lu ditampilkan dalam

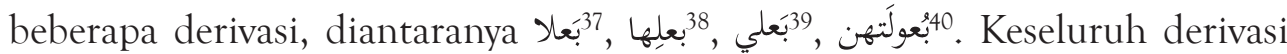
makna tersebut memiliki makna suami, kecuali pada Q.S al-Shaffat: 125, dimana kata $b a$ 'lan disana merupakan nama Tuhan atau berhala yang dahulu disembah oleh masyarakat Madinah. ${ }^{41}$

Adapun terkait kata zauj, dalam kamus Lisanul 'Arab dijelaskan bahwa

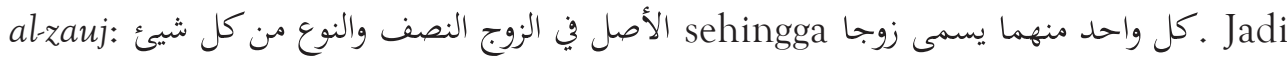
maksudnya makna asal dari al-zauj adalah belahan atau pecahan dari segala sesuatu. Sehingga segala sesuatu yang memiliki pecahan atau belahan baik itu belahannya maupun sesuatu itu sendiri (yang telah dibagi) disebut dengan al zanj. $^{42}$

Dalam makna definitif di atas, tidak nampak adanya pengkhususan dalam penggunaan kata al-zauj. Sehingga maksudnya disini kata al-zauj dapat digunakan kepada siapapun dan apapun.

Al-Qur'an menggunakan kata al-zauj tidak hanya ditujukan untuk manusia ${ }^{43}$. Melainkan juga digunakan untuk menunjukkan sesuatu yang lain seperti halnya buah-buahan ${ }^{44}$, hewan ${ }^{45}$, dan al-Qur'an bahkan mengatakan bahwa segala sesuatu diciptakan berpasangan ${ }^{46}$.

Adapun jika keduanya bermakna suami, maka keduanya juga memiliki perbedaan. Jika merujuk kepada kepada al-Qur'an yakni surah al-Baqarah: 230 dan 228, akan didapati sebuah spesifikasi. Dalam al-Baqarah: 230 kita

${ }^{36}$ Ibn Mandzur, Lisanul Arab, Kairo: Dar al-Ma'arif, 1119 H, h. 316-318.

${ }^{37}$ Q.S al-Shaffat: 125

${ }^{38}$ Q.S al-Nisa: 128

${ }^{39}$ Q.S al-Hud: 72

${ }^{40}$ Q.S al-Baqarah: 228; Q.S al-Nur: 31

${ }^{41}$ Lihat : al-Thabari, Jami' al-Bayan fi Tafsir Ay al-Qur'an, Jilid 21 (Versi Maktabah Syamilah), (Saudi: Muasasah al-Risalah, 2000, h. 96; Ibn Katsir, Tafsir al-Qur'an al-Adzhim, Jilid 7 (Versi Maktabah Syamilah), Saudi: Dar Thayyibah, 1999, h. 37.

${ }^{42}$ Ibn Mandzur, Lisanul Arab, Kairo: Dar al-Ma'arif, 1119 H, h. 1884-1886.

${ }^{43}$ Seperti pada Q.S al-Baqarah: 230

${ }^{44}$ Q.S al-Rahman :52

${ }^{45}$ Q.S Hud: 40

${ }^{46}$ Q.S al-Dzariyat: 49 
menemui kalimat حَنَّ تَنْكِح زَوْجَ yang dalam konteks ayatnya menjelaskan bahwa seorang suami yang telah bercerai dengan istrinya (3 kali talaq maka ia tidak diperbolehkan untuk mencampuri istrinya kembali sampai istrinya menikah dengan suami yang lain dan kemudian bercerai kembali dengan suaminya itu. ${ }^{47}$ Disana jelas al-Qur'an menggunakan kata zauj pada suami yang akan dinikahi. Berbeda halnya dengan dengan ayat sebelumnya dimana ditemukan kalimat

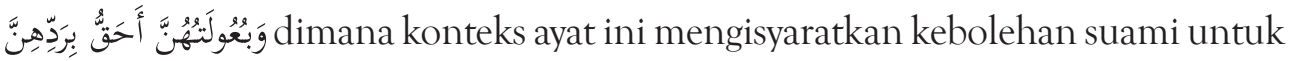
mencampuri kembali istrinya jika mereka bersepakat untuk rujuk.

Dari kedua ayat ini bisa temukan adanya perbedaan penggunaan pada kata zauj dan ba'l. Dimana kata zauj digunakan pada suami yang belum mencampuri istrinya sedangkan kata bu'l digunakan pada suami yang telah mencampuri istrinya.

Sehingga bisa disimpulkan bahwa kedua kata tersebut memang memiliki persamaan makna di satu sisi. Namun di sisi lain keduanya keduanya memiliki ciri khasnya masing-masing dimana kata al-bu'lu dalam al-Qur'an secara khusus dinisbatkan kepada manusia sedangkan kata al-zauj dinisbatkan kepada segala sesuatu secara umum. Serta adanya perbedaan penggunaanya saat sama-sama bermakna suami. Secara lebih jelas dapat dilihat di tabel berikut :

\begin{tabular}{|c|c|c|}
\hline No. & البعل & الزوج \\
\hline 1 & $\begin{array}{l}\text { Dinisbatkan penggunaanya khusus } \\
\text { kepada manusia (kecuali pada Q.S al- } \\
\text { Shaffat (37): } 125\end{array}$ & $\begin{array}{l}\text { Dinisbatkan penggunaannya secara } \\
\text { umum kepada segala sesuatu (manusia, } \\
\text { hewan, buah-buahan) }\end{array}$ \\
\hline 2 & $\begin{array}{l}\text { Dalam al-Qur'an secara umum mak- } \\
\text { nanya suami }\end{array}$ & $\begin{array}{l}\text { Dalam al-Qur'an maknanya menye- } \\
\text { suaikan dengan konteks kalimat dan } \\
\text { kepada siapa/apa penisbatannya. }\end{array}$ \\
\hline 3 & $\begin{array}{l}\text { Secara khusus maknanya adalah } \\
\text { suami yang telah mencampuri istrinya }\end{array}$ & $\begin{array}{l}\text { Jika maknanya "suami" maka yang di- } \\
\text { maksud adalah suami yang belum men- } \\
\text { campuri istrinya. }\end{array}$ \\
\hline
\end{tabular}

\section{Tentang Digital Literate Muslim Generation}

Dahulu dalam memahami al-Qur'am, orang-orang pada umumnya membutuhkan waktu yang cukup lama sebab keterbatasan yang ada. Khususnya di Indonesia, jika merujuk pada hasil penelitian Geertz yang membagi masyarakat Jawa kepada

${ }^{47}$ al-Qurthuby, al-Jami' al-Ahkam al-Qur'an, Jilid 3 Versi Maktabah Syamilah, Kairo: Dar al-Kutub al-Misriyah, 1964 h. 147. 
Millatī, Journal of Islamic Studies and Humanities, Vol. 3, No. 2, Des. 2018: 245-260

tiga tingkatan yakni abangan, santri dan priayi. ${ }^{48}$ Maka hanya golongan santri-lah yang memungkinkan untuk memahami ajaran agama khususnya al-Qur'an secara mendalam. Itupun harus melewati beberapa tingkatan kelas yang tentunya memakan waktu yang tidak sedikit.

Dewasa ini berbagai inovasi teknologi telah memberikan dampak yang begitu terasa bagi berlangsungnya tatanan kehidupan manusia. Perkembangan teknologi digital memungkinkan segala hal dapat diakses melalui media digital. Berbagai informasi maupun aplikasi penunjang dapat diunduh dengan mudah melalui ruang-ruang digital.

Hal ini juga turut berimbas pada munculnya beragam aplikasi al-Qur'an dan terjemahan yang mampu memberikan pengalaman beragama yang berbeda. Muhammad Sahal Sobirin menamai berbagai aplikasi al-Qur'an dan terjemahan ini sebagai mushaf jenis baru. Sebagai implikasi dari kemunculan mushaf jenis baru ini, lahirlah pula sebuah generasi muslim baru yang dinamai dengan Digital Literate Muslim Generation (Generasi Muslim Melek Digital). ${ }^{49}$

Dalam pandangan Muhammad Sahal Sobirin berdasarkan penelitiannya, ada tiga alasan yang menyebabkan generasi Muslim ini begitu bergantung kepada mushaf jenis baru ini, yakni : $:^{50}$

Pertama, aplikasi al-Qur'an dan terjemahan memberikan kemudahan guna melatih kebiasaan membaca al-Qur'an secara rutin. Karena dalam aplikasi tersebut terdapat reminder yang akan mengingatkan jadwal mengaji.Kedua, memberikan kesempatan yang lebih banyak guna mempelajari al-Qur'an secara intensif.Ketiga, karena mereka hidup di era digital, maka menjadi sebuah tuntutan bahwa al-Qur'an juga harus hadir dalam bentuk digital.

\section{Kritik Terhadap Digital Literate Muslim Generation}

Dalam pemaparan Muhammad Sahal, perkembangan generasi muslim melek digital ini merupakan sebuah fenomena yang terjadi sebagai implikasi dari perkembangan zaman. Dimana ia memaparkan bahwa media pembelajaran alQur'an saat ini cenderung mengarah kepada penggunaan media digital sebagai sarananya yakni melalui aplikasi al-Qur'an dan terjemah yang rata-rata berlisensi

${ }^{48}$ Lihat: Daniel L. Pals, Seven Theories of Religion, Yogyakarta: IRCiSoD, 2012, h 340-346.

${ }^{49}$ Muhammad Sahal Sobirin, "Digital Qur'an and Its Translation”, dalam Digital Religion: Understanding Religious Practice in New Media World, London: Routledge, 2013, h. 1-5.

${ }^{50}$ Muhammad Sahal Sobirin, "Digital Qur'an and Its Translation”, dalam Digital Religion: Understanding Religious Practice in New Media World, London: Routledge, 2013, h. 1. 
dan dibawah pengawasan Kementerian Agama.

Namun, berdasarkan teori la taradufa fi al-Qur'an yang telah diuraikan di atas, tentunya ada beberapa hal yang perlu diuraikan dan dikritisi dalam perkembangan pembelajaran al-Qur'an secara instan melalui media digital ini. Diantaranya:

Pertama, dalam teori la taradufa fi al-Qur'an terlihat bagaimana begitu kompleksnya kalamullah yang diturunkan pada Muhammad saw ini. Pemilihan kosa kata yang ada dalam al-Qur'an terlihat begitu detail dan teliti sehingga katakata yang umumnya dimaknai saling bersinonim pun ternyata dalam al-Qur'an difungsikan berdasarkan kegunaannya masing-masing sehingga memilki makna yang berlainan..$^{51}$

Kedua, jika ditarik secara lebih meluas, teori tersebut tentunya mengindikasikan bahwa dalam memahami al-Qur'an tidak cukup seseorang hanya membaca terjemahan saja. Justru perilaku inilah yang akan mengurangi nilai kemukjizatan al-Qur'an yang bahkan tercakup dalam setiap pemilihan diksi yang digunakannya. ${ }^{52}$

Ketiga, budaya memahami al-Qur'an melalui media digital yang hanya menampilkan terjemahan juga ditakutkan akan berimplikasi pada pemahaman terhadap al-Qur'an yang cenderung tekstualis dan tak paham konteks. Karena sejatinya dalam mempelajari dan memahami al-Qur'an dibutuhkan pemahaman terhadap ilmu-ilmu lainnya yang berfungsi sebagai alat bantu dalam memahami pesan-pesan yang tertuliskan dalam al-Qur'an secara komprehensif. ${ }^{53}$ Dengan begitu tidak heran jika banyak anak muda yang terjangkit virus-virus radikalisme akibat memahami ayat-ayat al-Qur'an hanya melalui terjemahan semata. ${ }^{54}$

Keempat, munculnya fenomena da'i medsos pun semakin marak, karena hanya dengan sekali klik ia mampu mengais berbagai informasi yang dibutuhkan guna mengampu profesinya sebagai pendakwah, padahal informasi yang didapatnya itu belum tentu keabsahannya bisa dipertanggungjawabkan kebenarannya. Sikap instan seperti inilah yang berimplikasi pada melemahnya tingkat literasi di tengah anak muda karena malas membuka kembali kitab-

${ }^{51}$ Aisyah Abdurrahman Bintu Syathi', al-I'jaz al-Bayani li al-Qur'an, Kairo: Dar al-Ma'arif, 2008, h. 211-213.

${ }^{52}$ Fadhil Muhammad al-Samirani, al-Ta'bir al-Qur'an, Kairo: Dar al-Ma'arif, 2000, h. 63-64.

${ }^{53}$ Lihat: Quraisy Shihab, Kaidah Tafsir, (Tangerang: Lentera Hati, 2015), h. 395-400.

${ }^{54}$ Nasaruddin Umar, Deradikalisasi Pemahaman al-Qur'an dan Hadis, (Jakarta: Quanta, 2014), h. 1-4. 
Millatī, Journal of Islamic Studies and Humanities, Vol. 3, No. 2, Des. 2018: 245-260

kitab ulama yang ahli dalam bidangnya (bidang al-Qur'an dan tafsir) yang telah bersusah payah menyusun penjelasan terhadap kalamullah dengan didasari atas tadabbur dan tafakkur yang mendalam. Serta timbulnya rasa ketidakbutuhan terhadap bimbingan guru dalam memahami pesan-pesan ilahi. ${ }^{55}$

Kelima, memang perkembangan teknologi yang merupakan implikasi dari globalisasi ini tidak dapat dielakkan dalam setiap tatanan kehidupan masyarakat. Namun satu hal yang perlu digarisbahwai yaitu dalam mengapresiasi perkembangan dan kemajuan teknologi, umat muslim tidak boleh serta-merta meninggalkan tradisi pengajaran Islam yang sudah ada sejak jaman awal kemunculan Islam. Dimana dalam mempelajari al-Qur'an, umat-umat terdahulu sudah menciptakan budaya pengajaran al-Qur'an melalui metode talaqi yakni melalui metode bertatapan langsung dengan seorang guru yang telah mahir dalam bidangnya dan bersanad hingga ke Rasulullah saw. ${ }^{56}$ Tanpa adanya metode pengajaran yang demikian niscaya pesan-pesan ilahiyah dalam al-Qur'an serta nilai kemukjizatannya-yang bahkan tercurah hanya dalam sebuah huruf-tak akan mampu kita rasakan saat ini. Jadi, jika budaya memahami al-Qur'an hanya berdasarkan aplikasi dan terjemah digital ini terus berlanjut tanpa adanya diimbangi dengan metode pembelajaran al-Qur'an yang baik, maka tinggal menunggu saja nilai mukjizat mana lagi yang berkurang kembali.

\section{Kesimpulan}

Teori la tarädufa fi al-Qur'anmemberikan penegasan terhadap aspek i'jaz al-Qur'an khususnya pada pemilihan diksi kosa-kata seperti yang telah dijelaskan. aspek i'jaz ini tentunya akan menambah kesadaran seorang muslim akan pentingnya bertadabbur dan bertafakkur terhadap kalamullah. ${ }^{57}$ Mencoba mendapatkan dan memahami pesan-pesan ilahiyah melalui pembelajaran langsung kepada guru yang kompeten dalam bidang al-Qur'an dan tidak asal hanya membaca dan

${ }^{55}$ Muchlishon, "Enam Efek Negatif Media Sosial Terhadap Literasi KeIslaman, Apa Saja?”,dalam www.nu.or.id/post/read/84194/enam-efek-negatif-media-sosial-terhadap-literasikeislaman-apa-saja, diakses pada 05/ 04/2018.

${ }^{56}$ Musthafa al-A'zami, Sejarah Teks al-Qur'an dari Wahyu sampai Kompilasi (terj.), (Depok: Gema Insani, 2014), h. 55-64. Lihat juga : Manna' al-Qathan, Mabahits fi Ulum al-Qur'an, (Surabaya: Maktabah al-Hidayah, 1973), h. 119-128.

${ }^{57}$ Imam al-Zarkasyi mengatakan bahwa bertadabbur dan bertafakkur adalah kunci untuk mendapatkan makna al-Qur'an yang haqiqi. Bukan seperti apa yang dianggap oleh ahl al-zhohir yang menganggap dengan memahami zhohir ayat saja sudah cukup untuk memahami pesa-pesan ilahiyah. Lihat: Al-Zarasyi, al-Burhan fi Ulum al-Qur'an, jilid 2. Kairo: Dar al-Ma'arif, 2000, h. 180. 
mengutip terjemah lalu menganggapnya sebagai pemahaman yang paling baik adalah metode yang terbaik yang bisa ditempuh dan harus senantiasa dilestarikan. Karena sesungguhnya memang terjemahan tidak bisa memberikan pemahaman yang komprehensif terhadap nash al-Qur'an. Dan justru malah mengurangi nilai kemukjizatan al-Qur'an sendiri.

Penggunaan moda teknologi secara proporsional juga merupakan langkah terbaik yang dapat dilakukan guna mencegah dampak buruk globalisasi. Maka sebagai upaya memajukan peradaban tentu generasi muslim juga harus cakap dalam memanfaatkan dunia digital yakni lewat penyebaran pesan-pesan universal Islam yang didasari atas pengetahuan yang teruji keabsahannya.

\section{Referensi}

Al-Qathan, Manna'. Mabahits fi Ulum al-Qur'an. Surabaya: Maktabah al-Hidayah, 1973.

Al-Qurthuby, al-Jami' al-Ahkam al-Qur'an, Jilid 9 (Versi Maktabah Syamilah). Kairo: Dar al-Kutub al-Misriyah. 1964.

Al-Samirani, Fadhil Muhammad. al-Ta'bir al-Qur'an. Kairo: Dar al-Ma'arif. 2000. Al-Thabari. Jami' al-Bayan fi Tafsir Ay al-Qur'an. Jilid 16 (Versi Maktabah Syamilah). Saudi: Muasasah al-Risalah. 2000.

Al-A'zami, Musthafa. Sejarah Teks al-Qur'an dari Wahyu sampai Kompilasi (terj.). Depok: Gema Insani. 2014.

Baqi, Muhammad Fuad Abdul. al-Mu'jam al-Mufahras li Alfadz al-Qur'an. Bandung: Diponegoro. 2010

Ghofur Saiful Amin. 2013. Mozaik Mufasir al-Qur'an dari Klasik Hingga Kontemporer. Yogyakarta : Kaukaba Dipantara.

Janam Nabilul. 2017. “Sinonimitas Dalam al-Qur'an (Analisis Semantik Lafadz Khauf dan Khasyyah) "Dalam Skripsi IAIN Surakarta.

Katsir, Ibn. Tafsir al-Qur'an al-Adzhim. Jilid 4 (Versi Maktabah Syamilah). Saudi: Dar Thayyibah. 1999.

L. Pals, Daniel. Seven Theories of Religion. Yogyakarta: IRCiSoD. 2012.

Mardan. 2011. "Tafsir Karya 'Aisyah 'Abd al-Rahman Bint Syathi' Suatu Rekontruksi Metodologi Tafsir Kontemporer” Adabiyah, Vol. XI. No. 2. Mu'jam digital, www.almaany.com, diakses pada 03/04/2018 
Millatī, Journal of Islamic Studies and Humanities, Vol. 3, No. 2, Des. 2018: 245-260

Muchlishon, "Enam Efek Negatif Media Sosial Terhadap Literasi KeIslaman, Apa Saja?",dalam www.nu.or.id/post/read/84194/enam-efek-negatif-mediasosial-terhadap-literasi-keislaman-apa-saja, diakses pada 05/ 04/2018

Rahim, Mahmud Abdur. al-Tafsir al-Nabawi. Kairo: Maktabah al-Zahra'. 2000.

Riyanto Waryani Fajar. 2014. "Antisinonimitas Tafsir Sufi Kontemporer" Episteme, Vol. 9. No.1.

Sobirin, Muhammad Sahal. "Digital Qur'an and Its Translation". dalam Digital Religion: Understanding Religious Practice in New Media World. London: Routledge. 2013

Shihab, Quraisy. Kaidah Tafsir. Tangerang: Lentera Hati. 2015.

Syamsuddin Sahiron, dkk. 2003. Hermeneutika al-Qur'an Mazhab Yogya. Yogyakarta: Penerbit Islamika.

Syathi, Aisyah Abdurrahman Bintu. al-I'jaz al-Bayani li al-Qur'an. Kairo: Dar al-Ma'arif. 2008.

Umar, Nasaruddin. Deradikalisasi Pemahaman al-Qur'an dan Hadis. Jakarta: Quanta. 2014.

Wahyuddin. 2011. "Corak dan Metode Interpretasi Aisyah Abdurrahman Bint al-Syathi”" al-Ulum, Vol. 11. No. 1. 